\title{
The Internationalization Process of Brazilian Companies: a Study of Multiple Cases in the Heavy Construction Industry
}

\author{
Flavia Luciane Scherer * \\ E-mail address: fscherer@smail.ufsm.br \\ Universidade Federal de Santa Maria \\ Santa Maria, RS, Brazil.

\section{Clandia Maffini Gomes} \\ E-mail address: clandia@smail.ufsm.br \\ Universidade Federal de Santa Maria \\ Santa Maria, RS, Brazil.

\section{Isak Kruglianskas} \\ E-mail address: ikruglia@usp.br \\ Faculdade de Economia, Administração e Contabilidade/Universidade de São Paulo \\ São Paulo, SP, Brazil.
}

\begin{abstract}
The aim of this article is to describe and to analyze how the consolidation in the international markets of Brazilian construction companies occurred. The methodological procedures had been classified as descriptive conclusive research and data was collected under a qualitative orientation. A study of four companies was conducted: Andrade Gutierrez, Mendes Júnior, Norberto Odebrecht and Queiroz Galvão. A theoretical model with four analytical levels was considered: the macro context, the institutional environment, the industry and the firm. The results indicate that consolidation in international markets occurred largely as a result of factors concerning strategic management in response to the institutional processes and the appropriateness of the sector's competitive conditions. In theoretical terms, this article makes progress when understanding internationalization processes is concerned in that it proposes a model that integrates knowledge from the fields of study of administration, organizations and international business. Although the model may be refined in future research, we believe that it reflects an important step toward the development of a broad theoretical frame of reference capable of covering the wealth and diversity that are typical of international activity.
\end{abstract}

Key words: internationalization process; consolidation; heavy construction.

Copyright (C) 2009 Brazilian Administration Review. All rights reserved, including rights for translation. Parts of this work may be quoted without prior knowledge on the condition that the source is identified.

\footnotetext{
* Corresponding author: Flavia Luciane Scherer

R. Floriano Peixoto, 1184, Santa Maria, RS, 97015-700, Brazil.
} 


\section{INTRODUCTION}

The intensified commercial flow among countries has integrated markets into a global business base, leading to new outlooks where companies' operations, within a context of heavy competition, are concerned. This movement drives the growing academic interest in the study of the phenomenon of internationalization and the processes involved in the management of companies that operate abroad.

Indeed, the importance of the internationalization of companies for the economic development of a country is an issue that stands out both in academic circles and in other arenas of debate. Despite the efforts already undertaken, there are only a few studies dealing with the internationalization of Brazilian firms (Arbix, Salerno, \& De Negri, 2004). When it comes to studies dealing with the ongoing presence of Brazilian companies abroad, these are even scarcer.

Therefore, this article aims to reduce the lack of studies in this field by employing an analytical point of view that centers on the study of the growth and consolidation stages in foreign markets postentry. The idea is to avoid emphasizing the discussion of the initial stage of international market entry, which has been the focus of the international marketing strategy studies so far (Douglas \& Craig, 1989). From this perspective, one must add the thoughts of Melin (1992), who felt it was a problem that most studies in this field focus their analysis on the early stages of internationalization. Following the same line of argument, one can add the point of view of Mata and Portugal (2004, p. 297), who emphasize that "entry and post-entry market penetration are two sides of the same coin" and who stress the importance of focusing on the post-entry period, rather than only on when companies first begin operating in foreign markets.

For Li (1995), the issue of survival in foreign markets is critical. From this standpoint, one gathers that although theoretical discussions in the literature about this issue are found, there are still only a few empirical studies dealing with the issues of performance and survival of foreign subsidiaries after entry in the target market. Li (1995) states that post-entry survival has been overlooked.

In order to enable empirical research, we chose to study heavy construction companies, as this was a pioneering segment where the internationalization of Brazilian companies is concerned; the authors hoped to find companies that had engaged in foreign operations for more than ten years. This longer time span is necessary because consolidation is a long-term measurement of the performance of an international subsidiary. From this perspective, it was possible to study the post-entry period and thus minimize the problem mentioned by Jiang and Bezmish (2004), namely that research into Foreign Direct Investment [FDI] has been examining matters in relation to point of entry or end of cycle issues, whereas the question of how firms actually grow and make a profit in foreign market is given only limited attention.

Taking these thoughts into account, this article was developed with the aim of describing and analyzing how the consolidation of Brazilian heavy construction companies with foreign direct investments took place in international markets.

\section{THEORETICAL FRAME OF REFERENCE}

We believe that one should analyze consolidation abroad based on a multivariate approach, given that the phenomenon is subject to complex and different influences. Foreign operations are subject to considerations that regard the macro context, the institutional environment, the industry and the firm itself.

The selection of the content needed to carry out this study took into account, besides the problematics and objectives described, the unique characteristics of the heavy construction industry 
that would be the basis for the empirical stage of the study. Because of the complexity that characterizes the sector and the aspects involved in the exporting of services, we assumed that it would be crucial to use a broad theoretical framework, separated into different levels. Therefore, we chose to follow the approach of Javalgi and White (2002), for whom the inherent differences between service and manufacturing companies imply the use of a contextual focus when it comes to understanding the internationalization of services.

In a study about the Brazilian auto parts industry, Rocha and Arkader (2002, p. 166) noted that the cases they studied "indicate that, in practice, the strategic movements under the pressures of globalization are an essentially rich and multidimensional phenomenon, which rarely fits with the existing theoretical models".

Taking into account the authors' arguments about the multidimensional nature of the phenomenon, we devised the theoretical model that is the basis of this study, in which we propose a broad approach that takes into account several levels of influence upon the operation of internationalized companies. Thus, we defined four levels of understanding, which meet in the ongoing interface of forces, resulting in processes subject to influences that are mutual, diverse and of different levels of complexity. We proposed that the consolidation of companies in international markets be studied on the basis of the relations between the macro context, the institutional environment, the industry and the firm. The proposed model can be seen in Figure 1.

\section{Figure 1: Multilevel Fame of Reference of the Factors that Condition Company Action in Foreign Markets}

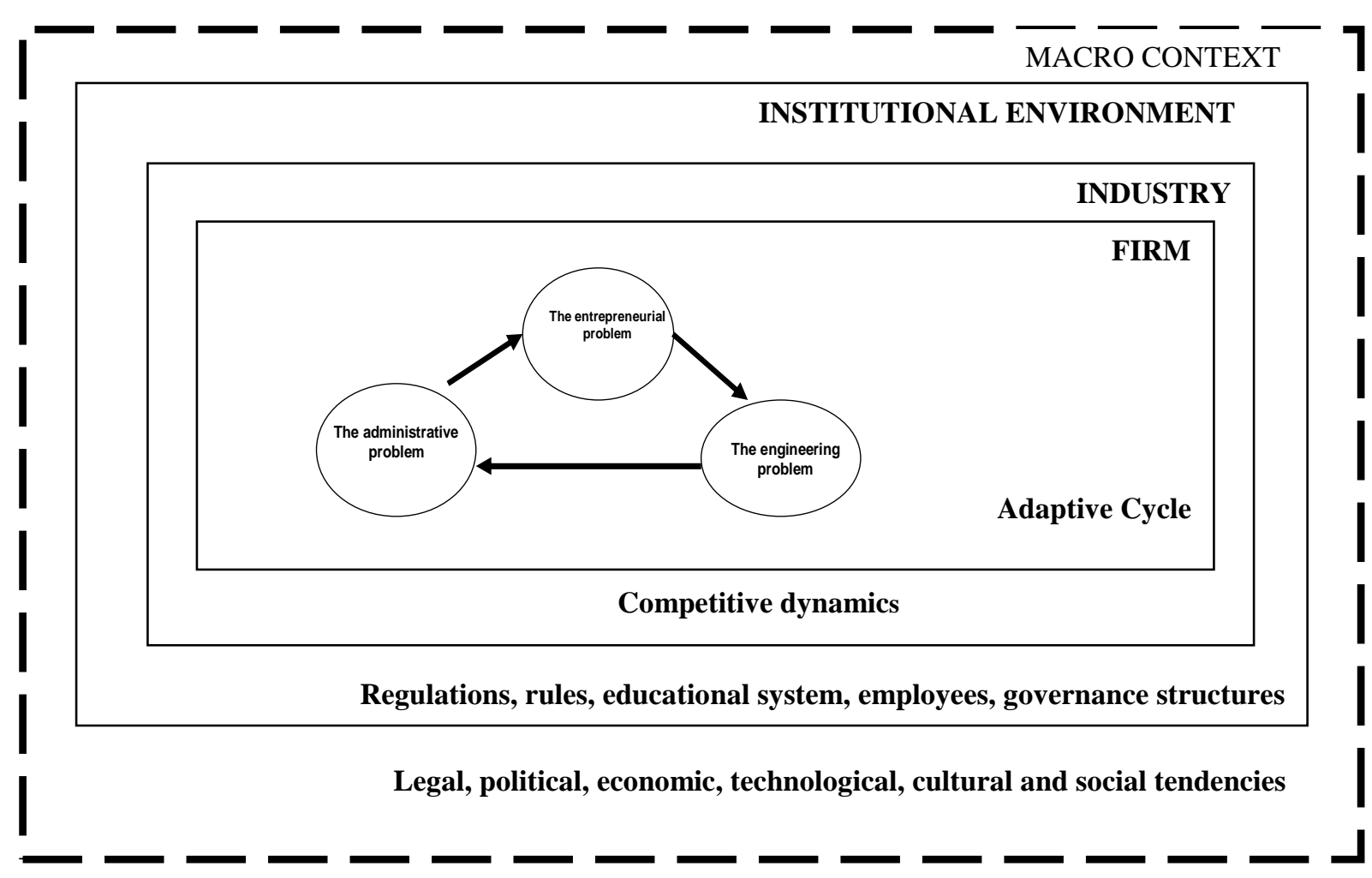

The broadest level is called the macro context. This is comprised of the set of legal, political, economic, cultural and social trends. This is the context that establishes the general tone of the competitive scene and that indicates to companies the possible paths that exist and the alternative scenarios, which will undoubtedly influence subsequent decisions. The trends indicate the direction that a given event or aspect appears to be taking. The mapping and the evaluation of the trends are under the employees' responsibility and therefore the process is encapsulated within the subjectivity of 
the point of view of those who conduct evaluations, prospect and finally make a decision, based on what they consider is most important or typical of a given context. One must take into account, therefore, the risks of a wrong analysis of the macro context. Aaker $(2001$, p. 105) states that

when one analyzes the environment, it is easy to get lost in a long and broad list of trends. To the contrary, one must limit the analysis to the areas that are sufficiently relevant and capable of having an impact on the strategy.

Consequently, one gathers that where the heavy construction segment is concerned, legal, political, economic, social and cultural trends are perforce subject to analysis because they represent aspects with a strong influence upon the definition of objectives and of business strategies. Because it is an industry whose chief customer is the government, the legal, political and economic trends call for ongoing monitoring, as changes in them influence and affect the behavior of the business. Similarly, penetrating foreign markets requires an in-depth knowledge of local culture and social aspects, and disregarding theses elements is one of the serious mistakes that a company can make when it goes international.

Taking these arguments into account, we enunciated two theoretical propositions regarding this level of analysis:

Among the macro context's tendencies, those of an economic nature have the greatest impact on international activity and on consolidation abroad; and

. A company's failure to adapt to local culture restricts its consolidation abroad.

Below, we have the institutional environment, comprised of standards, regulation rules, educational system influences, employee relations and other aspects that are typical of a given country's institutions. Institutions have multiple and intense influences and, where the sector under study is concerned, they are structures that play an important role when it comes to deciding whether to enter an international market, as well as where maintaining external operations is concerned. From the perspective of this environment, we look for explanations about the influence of institutions upon the activities of the heavy construction companies. Thus, we researched the behaviors of these institutions and attempted to understand the strategic responses to the pressures of institutions.

It was our understanding that these institutions represent a group with special influence and impact on the management of internationalized concerns, given that they demarcate the arena in which these organizations operate, as well as their operating style. Authors such as Scott (1995), Doz and Prahalad (1991), Meyer and Rowan (1991) and DiMaggio and Powell (1991) provided the basis for this argument. The concepts of isomorphism (mimetic, coercive and normative) put forth by DiMaggio and Powell (1991) and of the similarity among the organizations that belong to the same given population are central to the theory of institutions. Complementing this perspective, we found in Oliver (1991) the view that companies come up with different strategic responses to institutional pressures in order to attain positions that favor their operations and the results that they seek. According to this author, mere submission to the institutional environment is not always the best strategic response. There are times when firms embrace the posture of an active agent and of one that offers resistance to the institutional environment.

Therefore, the author suggests that the organizational responses vary in line with conformity to resistance, from passive to active, from pre-deliberate to controlled, from important to influential and from habitual to opportunistic, depending on the pressures to conform that the organizations encounter. With these variations in mind, she proposed a typology of strategic responses to institutional processes. The five strategies that she puts forth are acquiescence, commitment, evasion, challenge and manipulation.

This institutions-based perspective allows one to identify the deepest institutional influences and to evaluate how the organizational field has been structured over the years. Regarding institutions, it is worth highlighting what Rodrigues (2003) pointed out, i.e., that in general, institutions are seen as 
entities that model organizations in that they set the boundaries of managerial choices and behaviors. Not only do institutions set the boundaries of organizations and socialize them, but they can also carry society's macro ideas to the organizational level. This is precisely the relation between the external aspects and internal decisions that we intend to evaluate.

At the institutional environment level, the following theoretical propositions were studied empirically:

. Isomorphic processes are typical of the sector and influence decisions that concern foreign markets;

Political institutions have the strongest impact upon the international operation and its consolidation;

- Strategic responses to institutional pressures vary and may take on different degrees of submission or of active resistance.

The third level of analysis deals with the industry and its competitive dynamics. Looking at these elements from this angle, we tried to understand how the competitive movements in the Brazilian heavy construction industry took place. Regarding the sector's competitive dynamics, it is our understanding that the configuration of competitive relationships is simultaneously the cause and the effect of strategic decisions, including those that concern internationalization. A full understanding of comparative advantages regarding resources that can be converted into competitive advantages in the marketplace (Hunt, 2002) is one of the core arguments of this analytical level because it assumes that it contributes to a better understanding of the strategic decisions that have to do with foreign markets.

According to this author, firms holding positions of competitive advantage may maintain this situation if they continue to reinvest in the resources that produced the said competitive advantage and if the efforts of their rivals fail where the acquisition of resources and innovation are concerned. Hunt (2002) deals with competition from a point of view that considers the influence of other elements besides resources, position in the market and financial performance. The influence of resources and of social institutions, competitors and suppliers, consumers and public policies are also included in the author's model, adding to the analysis of competition an evaluative point of view that goes beyond the firm and that is in line with the study model proposed in this article.

The theoretical propositions concerning this level were:

In-depth knowledge of the specific resources that provide the company with comparative advantages is a determinant of consolidation in foreign markets.

- The dynamics of the competitive relations influences the possibility of consolidating international activity.

The narrowest analysis level, in terms of scope, is the fourth: the level of the firm and of its adaptive cycle. From this perspective, we attempted to identify the internal managerial aspects that explained the internationalization path of the companies studied, from the initial decision to the current state. We used the adaptive cycle dynamics of Miles and Snow (1978) as a map for the study because we believe that their assumptions provide an integrated and holistic overview of the strategic process of the companies studied. Thus, adaptation to the external environment, from a strategic point of view, is the key element at this level. Moreover, adaptation should be understood as a dynamic process that takes place on an ongoing basis by attacking the three major areas of decision-making: decisions concerning in-depth knowledge of product-market; decisions about technology; and decisions about the structure and processes that managing the business requires.

The authors' intention, underlying their proposal of the adaptive cycle, was to depict the nature and the interrelations between the key problems that an organization must solve in order to achieve a position of effectiveness in the chosen environment. Although adaptation is seen as a complex and continuous process, Miles and Snow believe that for the purposes of analysis it can be divided into three main problems that require upper management attention and decisions. 
Entrepreneurial problem. Both in new and in existing organizations, the solution is indicated by management acceptance of a particular understanding of product-market.

Egineering problem. This problem involves creating a system that puts into practice the administrative solution to the entrepreneurial problem.

. Administrative problem. This involves reducing uncertainty within the organizational system; in other words, the rationalization and stabilization of activities that advantageously solved the problems faced by the organization during the entrepreneurial stage and the engineering stage. It also involves formulating and implementing processes that will enable the organization to continue evolving.

The adaptive cycle emphasizes the dynamics of the organizational adaptation process. The three problems and their respective solutions involve the organization as a whole and their effects extend over more than one cycle. As a result of the decisions concerning the adaptive cycle, companies operate in such a way as to mold their environments. In other words, they do not assume the passive attitude of merely responding to change. The intentional character of managerial action is decisive for the process as a whole. These are strategic choices that will shape structures and processes, as well as the way in which the company will relate to its business environment.

The theoretical propositions for this level were the following:

- In international markets, decisions concerning each one of the problems of the adaptive cycle call for new solutions to the other problems.

. The adjustment between the solutions to the administrative, engineering and entrepreneurial problems is a determining factor for consolidation in foreign markets.

Given these levels of analysis, consolidation should be understood as the result of the strategic responses to multivariate influences upon the company, both internal and external. In principle, the four perspectives proposed in the theoretical model impose limitations and offer opportunities that may or may not result in consolidation abroad, which is precisely what this article proposes to examine.

\section{Methodology OUTLINE}

The procedures conducted were classified as descriptive conclusive research (Malhotra, 2001) in terms of the type of research that was carried out. Data collection was performed under a largely qualitative approach, chosen because the authors wished to "discover deeper relations among the elements and processes" (Gonçalves \& Meireles, 2004, p. 45).

Choosing to conduct the study on a qualitative basis was more appropriate, since the type of problem studied, the identification of the firms that fulfilled the study's requirements (being large and having more than 10 years of international activity) and the mapping of possible sources of evidence indicated that a survey type of study would not be feasible due to the impossibility of fulfilling the prerequisites for this kind of study.

Regarding the research strategy, this was a multiple-case study. Four large Brazilian companies from the heavy construction sector were researched: Andrade Gutierrez, Norberto Odebrecht, Mendes Júnior and Queiroz Galvão, which will not be identified in the presentation of results. The choice of these four companies for this study complied with two fundamental criteria: first, relevance: all of them were considered capable of contributing to the study and fit the selection criteria; and second, possibility: they were also the companies that were willing to take part in the study, providing access 
to the organization, supplying information and allowing interviews to be held with their senior executives.

The data for this article was taken from both primary and secondary sources. Primary data was obtained through semi-structured interviews. Secondary data was obtained from the companies' reports and/or publications and their websites. In the case of Mendes Júnior and Norberto Odebrecht, we also used material from books published by their presidents. Furthermore, data was sought in specialized journals and newspapers, as well as in prior research. The observation units (Table 1) comprised senior executive directors with internationalization experience and know-how.

Table 1: Observation Units

\begin{tabular}{|c|c|}
\hline Company & Interviewees' position \\
\hline Andrade Gutierrez (MG) & $\begin{array}{ll}- & \text { International Director } \\
\text { - } & \text { Legal Services Director } \\
\text { - } & \text { Former Legal Services Director }\end{array}$ \\
\hline Queiroz Galvão (RJ) & $\begin{array}{ll}\text { - } & \text { Technology and Management Support Director } \\
\text { - } & \text { International Director } \\
\end{array}$ \\
\hline Mendes Júnior (MG) & $\begin{array}{ll}- & \text { President } \\
\text { - } & \text { Engineering - Technology Executive Director (former deputy director } \\
\text { of the international area) } \\
\text { - } \quad \text { Member of the Board of Directors }\end{array}$ \\
\hline Norberto Odebrecht (RJ) & $\begin{array}{l}\text { - Former president and member of the Board of Directors } \\
\text { - } \quad \text { Institutional Relations Director }\end{array}$ \\
\hline
\end{tabular}

When it came to data treatment, we opted for content analysis, believing this to be a suitable method when the phenomenon under observation is communication (Malhotra, 2001). Bardin (2004) clarifies that based on a set of techniques, the researcher "works with words, i.e., the practice of the language carried out by identifiable issuers" (Bardin, 2004, p. 38). Thus, communication, whether conveyed orally or recorded in documents, is the subject of the researcher's analysis and the material to which analytical techniques will be applied.

Among the many content analysis techniques, we chose category analysis, the oldest form of content analysis. "It works by having the text divided into units, into categories, in accordance with analogical regroupings" (Bardin, 2004, p. 147). Categorization offers different application possibilities, the investigation of themes or thematic analysis having been chosen.

For this study, the starting point consisted of previously defined analysis categories based on the theoretical frame of reference used and the research model proposed for this study (Table 2).

Table 2: Categories Analyzed

\begin{tabular}{|c|c|}
\hline CATEGORY & SUB-CATEGORY \\
\hline 1. Macro context & $\begin{array}{l}\text { 1.1 Trends } \\
\text { 1.2 Perception relative to the influence of the macro context } \\
\text { 1.3 Monitoring }\end{array}$ \\
\hline 2. Institutional environment & $\begin{array}{l}\text { 2.1 Influence of the institutions } \\
\text { 2.2 Strategic responses to institutional pressures } \\
\text { 2.3 Isomorphic processes /homogenization of the field }\end{array}$ \\
\hline 3. Heavy construction industry & $\begin{array}{l}\text { 3.1 Competition } \\
\text { 3.2 Competitive dynamics }\end{array}$ \\
\hline $\begin{array}{l}\text { 4. Management of the } \\
\text { construction companies }\end{array}$ & $\begin{array}{l}\text { 4.1 Management processes } \\
\text { 4.2 Adaptive cycle: dynamics and decisions } \\
\text { 4.3 Internationalization within the context of business strategy: } \\
\text { paths, choices, results and outlook. }\end{array}$ \\
\hline
\end{tabular}




\section{RESULTS}

The first category of data analysis comprises the notion of macro context, encompassing trends, the perception of the macro context's influence and monitoring. The data obtained (Table 3 ) indicated that three of the four companies studied felt economic influences were the most important ones where international operation is concerned.

\section{Table 3: Macro Context: Synthesis}

\begin{tabular}{|c|c|c|c|c|}
\hline Subcategory & $\begin{array}{c}\text { Construction } \\
\text { company } 1\end{array}$ & $\begin{array}{c}\text { Construction } \\
\text { company } 2\end{array}$ & $\begin{array}{c}\text { Construction } \\
\text { company } 3\end{array}$ & $\begin{array}{c}\text { Construction } \\
\text { company } 4\end{array}$ \\
\hline Trends & \multicolumn{4}{|c|}{$\begin{array}{l}\text { Resumption of public investment in infrastructure in Brazil; opportunities to build for } \\
\text { private clients in the construction market; in the international market: growth } \\
\text { opportunities. }\end{array}$} \\
\hline $\begin{array}{l}\text { Perception of macro } \\
\text { context influence }\end{array}$ & $\begin{array}{l}\text { Strong. They have } \\
\text { rethought structure and } \\
\text { management. } \\
\text { Macroeconomic } \\
\text { aspects stand out. }\end{array}$ & $\begin{array}{l}\text { Strong. } \\
\text { the } \\
\text { influence. }\end{array}$ & $\begin{array}{l}\text { Strong. Focus on the } \\
\text { company's insertion } \\
\text { within society to } \\
\text { facilitate response. }\end{array}$ & $\begin{array}{l}\text { Strong. Focus } \\
\text { on the } \\
\text { environment's } \\
\text { instability. }\end{array}$ \\
\hline Monitoring & $\begin{array}{l}\text { Formalized: eventual. } \\
\text { Abroad, by employees } \\
\text { who know the market. }\end{array}$ & $\begin{array}{l}\text { Passive. It is } \\
\text { monitored rather } \\
\text { than in charge of } \\
\text { monitoring. }\end{array}$ & $\begin{array}{l}\text { Responsibility of the } \\
\text { local president. } \\
\text { Focus on new } \\
\text { business with long } \\
\text { term prospects. } \\
\text { Results above } \\
\text { processes. }\end{array}$ & $\begin{array}{l}\text { Not formalized. } \\
\text { Abroad, works } \\
\text { through } \\
\text { partnering } \\
\text { arrangements. }\end{array}$ \\
\hline
\end{tabular}

Only in construction company 3 were social and cultural aspects considered more relevant, which corroborated the point of view of Patterson and Cicic (1995), who warned that due to the more frequent and closer contact between services suppliers and clients, cultural sensitivity and awareness have extra importance for firms that render services.

The analysis of the institutional environment category indicated that companies feel a heavy impact from institutions, in particular from the state, unions and local culture. The companies act relative to them in such a way as to achieve the most favorable results for their operations. The study revealed different strategic responses between companies and within each company, depending on the aspects concerned (Table 4).

Table 4: Institutional Environment: Synthesis

\begin{tabular}{|c|c|c|c|c|}
\hline Subcategory & $\begin{array}{l}\text { Construction } \\
\text { company } 1\end{array}$ & $\begin{array}{c}\text { Construction company } \\
2\end{array}$ & $\begin{array}{c}\text { Construction company } \\
3\end{array}$ & $\begin{array}{c}\text { Construction } \\
\text { company } 4\end{array}$ \\
\hline $\begin{array}{l}\text { Influence of } \\
\text { institutions. }\end{array}$ & $\begin{array}{l}\text { The state as a } \\
\text { financial agent; } \\
\text { diplomacy as a } \\
\text { point of support: } \\
\text { variable } \\
\text { performance; } \\
\text { strength of the } \\
\text { local culture and of } \\
\text { the unions. }\end{array}$ & $\begin{array}{l}\text { The state as a supporter } \\
\text { vs. the state as an outlaw; } \\
\text { power of local culture. }\end{array}$ & $\begin{array}{l}\text { Fundamental: } \\
\text { awareness of the local } \\
\text { culture; the state as a } \\
\text { financial agent; } \\
\text { internationalization: } \\
\text { Brazilian geopolitics; } \\
\text { reaching a } \\
\text { compromise with } \\
\text { society; strength of } \\
\text { the unions. }\end{array}$ & $\begin{array}{l}\text { The state as a } \\
\text { client; diplomacy } \\
\text { is important, but } \\
\text { does not take } \\
\text { much action; } \\
\text { strength of the } \\
\text { unions. }\end{array}$ \\
\hline
\end{tabular}


Table 4 (continued): Institutional Environment: Synthesis

\begin{tabular}{|l|l|l|l|l|}
\hline \multicolumn{1}{|c|}{ Subcategory } & \multicolumn{1}{|c|}{$\begin{array}{c}\text { Construction } \\
\text { company 1 }\end{array}$} & $\begin{array}{l}\text { Construction company } \\
2\end{array}$ & $\begin{array}{l}\text { Construction company } \\
3\end{array}$ & $\begin{array}{c}\text { Construction } \\
\text { company } 4\end{array}$ \\
\hline $\begin{array}{l}\text { Strategic } \\
\text { responses to } \\
\text { institutional } \\
\text { pressures. }\end{array}$ & $\begin{array}{l}\text { Union problems: } \\
\text { evasion; with } \\
\text { clients: cooptation; } \\
\text { political lobby in } \\
\text { this sector: } \\
\text { influence. }\end{array}$ & $\begin{array}{l}\text { Country choice: } \\
\text { obedience; in Iraq: } \\
\text { obedience; post-judicial } \\
\text { enforcement: attack. }\end{array}$ & $\begin{array}{l}\text { Country choice: } \\
\text { obedience; } \\
\text { institutional } \\
\text { requirements: } \\
\text { obedience; relative to } \\
\text { opinion leaders: } \\
\text { cooptation. }\end{array}$ & $\begin{array}{l}\text { Adaptation to } \\
\text { local culture: } \\
\text { balance. }\end{array}$ \\
\hline $\begin{array}{l}\text { Isomorphic } \\
\text { processes / } \\
\text { homogenizatio } \\
\text { n of the field. }\end{array}$ & $\begin{array}{l}\text { Core assumption: Belonging to the club } \\
\text { Normative isomorphism: professionalization of the field. Engineering as the dominant } \\
\text { profession. } \\
\text { Mimetic isomorphism: 2 as the internationalization model, even after the Iraq crisis. } \\
\text { Mimetic isomorphism: 3 as the current internationalization model, }\end{array}$ \\
\hline
\end{tabular}

With regard to isomorphic processes, they were found to occur and, generally speaking, represent an attempt to belong to the club. In other words, the adoption of similar managerial practices seemed to be influenced by what other companies and the sector as a whole were doing. The preliminary hypothesis that company 2 , which pioneered internationalization, had served as a model was ratified by the interviewees' statements, with the qualification that this was only the case while it was at an intense level of international involvement and growth. In more recent stages, it was construction company 3 that stood out as a model for the rest of the sector.

The industry level analysis confirmed that the sector has marked specificities. In terms of competition, there seems to be a two-way system at play: the companies are competitors and business partners simultaneously, whether preparing proposals or when construction projects are concerned. The rising level of technical and managerial qualification requirements was also identified as one of the sector's characteristics.

In the context of the heavy construction sector, the formation of partnerships among business competitors through consortia or other arrangements is not unusual. This is because there are few occasions when a large project is executed by a single company. The creation of the consortium fortifies the partners because one offers resources that supply the what the other companies lack in terms of equipment and technology, technical experience or even financial capacity. In this way, it provides substantial benefits to the performance of the partnership.

The client (whether public or private) often stipulates the conditions for the project's implementation, and the formation of consortia may be one of these requirements. Thus, when prospecting markets, many companies look for partners to constitute the consortia.

Even in the exploratory analysis it was highlighted that, in many of the competitive situations, the companies' behavior tended to collusion (Raju \& Roy, 1999), where companies jointly defined prices in order to maximize their profits.

In the exploratory phase of the study, there was already evidence that this practice was commonplace among heavy construction companies, especially when the clients were of the public sector. Sometimes it happens that the companies make previous arrangements, in which they define together the price of their proposals and agree on who will be the winner of competition.

However, the interviews did not confirm the exploratory phase. When questioned about the possibility of collusion between competitors, responses ranged from discontent about the question to the affirmation that this belongs to the past.

The assumption that the pioneering character of construction company 2 in the area of internationalization and its results might influence the sector's competitive dynamics was not fully 
confirmed. This company's influence at first emerged as a model to be followed, but after its problems in Iraq it became an example to be avoided. Concerning competitive dynamics specifically, it seems that issues pertaining to the nature of the construction undertakings and the type of contract had a stronger influence, which deserves to be underscored (Table 5).

Table 5: Heavy Construction Industry: Synthesis

\begin{tabular}{|l|l|c|c|c|}
\hline \multicolumn{1}{|c|}{ Subcategorys } & \multicolumn{1}{c|}{$\begin{array}{c}\text { Construction } \\
\text { company } 1\end{array}$} & $\begin{array}{c}\text { Construction } \\
\text { company } 2\end{array}$ & $\begin{array}{c}\text { Construction } \\
\text { company } 3\end{array}$ & $\begin{array}{c}\text { Construction } \\
\text { company } 4\end{array}$ \\
\hline Competition & $\begin{array}{l}\text { Two-way dynamics: the companies compete } \\
\text { they may also be parthers in certain construction undertakings. }\end{array}$ \\
\hline $\begin{array}{l}\text { Competitive } \\
\text { dynamics }\end{array}$ & $\begin{array}{l}\text { Enhanced competitiveness - hypercompetition. Unit price contracts vs. closed price } \\
\text { contracts: increased complexity of management and of the demand for competencies. }\end{array}$ \\
\hline
\end{tabular}

At the company level, the research findings point to different management process configurations (Table 6). In each case, an overarching premise under which the other processes and decisions were handled was identified. For company 1, the main management guideline was defined as improving results. In the case of company 2 , it was focus on maintaining the technical and operating capacity of our engineering, associated with the company's brand. Where case 3 is concerned, the focus was to serve the customer through decentralized management, while company 4's management guideline was the need for financial security. We found that the image projected and the actions undertaken by the researched companies were congruent.

\section{Table 6: Management's Main Guideline}

\begin{tabular}{|c|c|}
\hline Company & Management guideline \\
\hline $\begin{array}{c}\text { Construction } \\
\text { company } 1\end{array}$ & $\begin{array}{l}\text { Improving results. The rational use of the capital employed, shareholder value } \\
\text { generation, ongoing management cost reduction, strict attention to cash generation } \\
\text { and the application of technologies are emphasized, besides modern processes for } \\
\text { increasing productivity and the recognition of the value of human resources. When } \\
\text { profit falls, all of us suffer. Disseminating the culture of performance. }\end{array}$ \\
\hline $\begin{array}{r}\text { Construction } \\
\text { company } 2\end{array}$ & $\begin{array}{l}\text { Focus on maintaining the technical and operating capacity of engineering, } \\
\text { associated with the company's brand. 'The quality seal that characterizes all of } \\
\text { the Group's projects and businesses must be maintained and continuously } \\
\text { improved by each person. The company's operation is based on the permanent } \\
\text { pursuit of operating and technological excellence, on the respect for contracts and } \\
\text { on an ethical and responsible posture, with the company positioning itself at the } \\
\text { forefront of economic and social development. }\end{array}$ \\
\hline $\begin{array}{r}\text { Construction } \\
\text { company } 3\end{array}$ & $\begin{array}{l}\text { Serving the client through decentralized management. We are an organization } \\
\text { of people who desire to serve and work with other people. At the base of Enterprise } \\
\text { Technology we will always find decentralization as the cornerstone. The } \\
\text { fundament of company life: one must always serve more and more, and } \\
\text { increasingly better. }\end{array}$ \\
\hline $\begin{array}{r}\text { Construction } \\
\text { company } 4\end{array}$ & $\begin{array}{l}\text { Financial security. Prioritizing liquidity is a point of honor for us. We don't } \\
\text { jeopardize company security. Maintaining sound financial status is an essential } \\
\text { competence. The company's profitability reflects conservative financial } \\
\text { management, which prioritizes growth based on its own resources. }\end{array}$ \\
\hline
\end{tabular}

Still considering the analysis of the construction company management category, the use of the adaptive cycle as a structure for the analysis of strategic management proved to be viable in relation to the purposes of the study. It also highlighted that decisions about the three problems were made in an integrated and interdependent manner (Table 7). 
Table 7: Adaptive Cycle: Synthesis

\begin{tabular}{|c|c|c|c|c|}
\hline Subcategory & $\begin{array}{l}\text { Construction } \\
\text { company } 1\end{array}$ & $\begin{array}{c}\text { Construction company } \\
2\end{array}$ & $\begin{array}{l}\text { Construction } \\
\text { company } 3\end{array}$ & $\begin{array}{l}\text { Construction } \\
\text { company } 4\end{array}$ \\
\hline $\begin{array}{l}\text { Enterpreneuri } \\
\text { al problem } \\
\text { (product- } \\
\text { market } \\
\text { domain) }\end{array}$ & $\begin{array}{l}\text { Product: active in } \\
\text { engineering areas } \\
\text { Market: Brazil and } \\
\text { Latin America } \\
\text { Product-market } \\
\text { Domain: recent } \\
\text { reorientation } \\
\text { Projected Image: } \\
\text { Competence that } \\
\text { overcomes } \\
\text { boundaries }\end{array}$ & $\begin{array}{l}\text { Product: active in } \\
\text { engineering areas } \\
\text { Market: Brazil (after } \\
\text { 2004) } \\
\text { Product-market } \\
\text { Domain: Definition } \\
\text { being narrowed. } \\
\text { Projected Image: } \\
\text { Solutions with } \\
\text { excellence in } \\
\text { engineering businesses }\end{array}$ & $\begin{array}{l}\text { Product: areas of } \\
\text { operation defined in } \\
\text { terms of } \\
\text { competencies } \\
\text { Product-market } \\
\text { Domain: Brazil and } \\
\text { the world } \\
\text { Projected Image: } \\
\text { Engineering and } \\
\text { construction leader } \\
\text { in Latin America }\end{array}$ & $\begin{array}{l}\text { Product: active in } \\
\text { engineering areas } \\
\text { Product-market } \\
\text { Domain: Brazil and } \\
\text { Latin America } \\
\text { Projected Image: } \\
\text { Expand brand and } \\
\text { quality }\end{array}$ \\
\hline $\begin{array}{l}\text { Engineering } \\
\text { problem } \\
\text { (technology } \\
\text { for } \\
\text { production } \\
\text { and } \\
\text { distribution) }\end{array}$ & $\begin{array}{l}\text { Technical quality } \\
\text { associated with } \\
\text { efficient cost } \\
\text { management }\end{array}$ & $\begin{array}{l}\text { Partnership with the } \\
\text { largest and the best for } \\
\text { access to cutting-edge } \\
\text { technology }\end{array}$ & $\begin{array}{l}\text { Acquisition of } \\
\text { companies to obtain } \\
\text { technological know- } \\
\text { how quickly and to } \\
\text { gain access to } \\
\text { markets }\end{array}$ & $\begin{array}{l}\text { Expanded notion of } \\
\text { technology } \\
\text { Financial soundness } \\
\text { vs. technological } \\
\text { up-to-dateness }\end{array}$ \\
\hline $\begin{array}{l}\text { Administrati } \\
\text { ve problem } \\
\text { (to } \\
\text { rationalize } \\
\text { the structure } \\
\text { and } \\
\text { processes } \\
\text { and to } \\
\text { evolve) }\end{array}$ & $\begin{array}{l}\text { Organizational } \\
\text { structure change. } \\
\text { Programs for } \\
\text { qualifying staff and } \\
\text { creating a common } \\
\text { basis for action. } \\
\text { Succession of } \\
\text { generations }\end{array}$ & $\begin{array}{l}\text { Management } \\
\text { Technology Project: } \\
\text { upgrading management } \\
\text { practices and ensuring } \\
\text { that they are put into } \\
\text { practice at all levels. } \\
\text { Centralizing practices. } \\
\text { Concern with the } \\
\text { rationalization of } \\
\text { structures and } \\
\text { processes. }\end{array}$ & $\begin{array}{l}\text { Enterprise } \\
\text { Technology- } \\
\text { common knowledge } \\
\text { base. Decentralized } \\
\text { operations with full } \\
\text { and planned } \\
\text { delegation. }\end{array}$ & $\begin{array}{l}\text { Integrated } \\
\text { Management } \\
\text { System training } \\
\text { programs regarding } \\
\text { the Integrated } \\
\text { Management } \\
\text { Policy. Company's } \\
\text { perpetuity: } \\
\text { shareholders } \\
\text { convention. }\end{array}$ \\
\hline
\end{tabular}

The analysis of the internationalization processes subcategory (Table 8) in the four companies did not reveal any substantial differences. On the contrary, the approach found was practically the same. The venture into foreign markets occurred primarily as part of a strategy designed to face the scarcity of construction projects in Brazil. Construction company 2 was the exception in this case due to the fact that it initiated its internationalization during a period in which the Brazilian market for public construction projects was still generous. 
Table 8: Internationalization: Synthesis

\begin{tabular}{|c|c|c|c|c|}
\hline Subcategory & $\begin{array}{c}\text { Construction } \\
\text { company } 1\end{array}$ & $\begin{array}{c}\text { Construction } \\
\text { company } 2\end{array}$ & $\begin{array}{c}\text { Construction } \\
\text { company } 3\end{array}$ & $\begin{array}{c}\text { Construction } \\
\text { company } 4\end{array}$ \\
\hline $\begin{array}{l}\text { Internatio- } \\
\text { nalization }\end{array}$ & $\begin{array}{l}\text { Start:1984, Congo } \\
\text { Reason: an alternative } \\
\text { to the scarcity of } \\
\text { construction projects } \\
\text { in Brazil. } \\
\text { Results: positive in } \\
\text { the first few projects } \\
\text { (decision to bet on the } \\
\text { potential, on the } \\
\text { culture and on } \\
\text { international } \\
\text { exposure). } \\
\text { Means of entry: it } \\
\text { varies, depending on } \\
\text { the client. } \\
\text { Learning process: led } \\
\text { to redefinition of } \\
\text { orientation (a } \\
\text { minimum team of } \\
\text { Brazilians abroad and } \\
\text { a Portuguese } \\
\text { subsidiary for } \\
\text { Europe). } \\
\text { Strategic planning: } \\
\text { current focus on Latin } \\
\text { America (restriction). } \\
\text { Permanence regarding } \\
\text { structure } \\
\text { maintenance: } \\
\text { Sees itself as } \\
\text { consolidated.'It } \\
\text { learned more than it } \\
\text { taught." }\end{array}$ & $\begin{array}{l}\text { Start: 1969, Bolivia. } \\
\text { Vocation for } \\
\text { internationalization } \\
\text { Reasons for going } \\
\text { international: to } \\
\text { diversify risk. } \\
\text { Africa: government } \\
\text { incentives. } \\
\text { Means of entry: } \\
\text { partnerships with } \\
\text { major companies. } \\
\text { 1978, Iraq: pursuit of } \\
\text { opportunities, } \\
\text { political and religious } \\
\text { facilities, reciprocity. } \\
\text { Late } 80 \text { s: a market } \\
\text { that offered an } \\
\text { alternative to the } \\
\text { crisis (return to Latin } \\
\text { America). } \\
\text { Chile: focus from } \\
\text { 1989 to 2004. Entry } \\
\text { with local partner } \\
\text { (strategic country to } \\
\text { "stay alive" in the } \\
\text { international } \\
\text { market'). } \\
\text { 2004: withdrawal } \\
\text { (focus on Brazil) } \\
\text { Priority: to collect } \\
\text { past-due receivables } \\
\text { through lawsuits. }\end{array}$ & $\begin{array}{l}\text { Start: 1979, Peru and } \\
\text { Chile; 1980, Africa. } \\
\text { Reason: in response } \\
\text { to public investment } \\
\text { reduction. } \\
\text { Continuous expansion } \\
\text { of international } \\
\text { presence: 1990, First } \\
\text { World - USA focus, } \\
\text { to develop } \\
\text { competitiveness. } \\
\text { Means of entry: } \\
\text { varied: local laws and } \\
\text { opportunities. } \\
\text { Always with local } \\
\text { partners. } \\
\text { 2003: Middle East. } \\
\text { Choice of countries: } \\
\text { long term expectation } \\
\text { - "50 years". Having } \\
\text { the right professional } \\
\text { for making decisions: } \\
\text { "having the man". } \\
\text { Perpetualness: } \\
\text { arrangement with } \\
\text { local company, } \\
\text { entrepreneurs- } \\
\text { partners, enterprise } \\
\text { technology. } \\
\text { Global organization } \\
\text { based in Brazil. "To } \\
\text { survive, grow and } \\
\text { perpetuate itself". }\end{array}$ & $\begin{array}{l}\text { Start: 1984: Uruguay } \\
\text { (negative results); } \\
\text { 1992: structuring of } \\
\text { the international area } \\
\text { 1994: Bolivia - } \\
\text { resumption of } \\
\text { international activity } \\
\text { Reasons for going } \\
\text { international: } \\
\text { competing with } \\
\text { multinationals and } \\
\text { maintaining its } \\
\text { billings. } \\
\text { Focus: Latin America } \\
\text { Reason why: physical } \\
\text { and cultural proximity } \\
\text { and contracts of a } \\
\text { lower value. } \\
\text { Means of entry: } \\
\text { Consortiums with } \\
\text { smaller companies. } \\
\text { Expansion process: } \\
\text { conservative. } \\
\text { Future: expand to } \\
\text { Africa, the Middle } \\
\text { East and the USA; } \\
\text { consolidated in Latin } \\
\text { America. } \\
\text { Results: financial } \\
\text { results still negative; } \\
\text { positive results in } \\
\text { terms of experience, } \\
\text { maturity, cultural } \\
\text { improvement and as a } \\
\text { basis for the future. } \\
\text { Future: promising. }\end{array}$ \\
\hline
\end{tabular}

In the case of construction companies, in order to enter other countries, it is mandatory to establish a local subsidiary, which must be formalized prior to construction start-up. To present projects and build them in other countries, the companies must be legally established in these places. In order to reduce a relative lack of knowledge about market conditions, the cases studied revealed that the companies, as a rule, work with local partners. From this point of view, the thesis of Nicolaud (1989) is corroborated. According to him, service companies do not have the same learning process opportunities, based on gradual experience, that other producers of goods enjoy, as the latter can experience indirect or casual exporting.

The association with local partners allows companies to quickly acquire knowledge of the local market and minimize the typical risks of the adjustments to another country's requirements. To minimize cultural differences is one of the main objectives of these partnerships, but it is also important to acquire knowledge of local legislation. 
In addition, it is necessary to consider that the partnership with a local company may be a formal requirement to enter and to stay in some countries. This is the case, for example, of China, where association with local firms is mandatory for engineering operations.

According to the respondents, local partners are kept where they ensure good results for the Brazilian companies. In some cases, the change of partners can occur, but the partnership with a local company is generally kept because it is considered strategic in the process of adaptation to the local culture.

Respondents expressed the belief that, independently of time of operation of the Brazilian companies in another country, they will always be considered foreign companies. Therefore, it would always be easer for a local company to do business with local clients (whether public or private).

Patterson and Cicic (1995) voiced similar views when they stated that service companies must be on foreign soil from the very first day of their international activity. Local presence is necessary, especially in situations in which the service offered is customized, this being the typical case of engineering and construction services.

In the case of the companies studied, maintaining foreign activities met other criteria besides profitability. The construction companies believe that foreign operations are important in order to achieve higher development levels, both in technical and in managerial terms. In this case, belonging to the club may explain their permanence in part, especially during times when the companies suffer a retraction of their profitability levels.

It was also explained that foreign operations had to be maintained because of the need for constant upgrading, which can only be achieved through ongoing construction activity in sites with different profiles and requirements. Thus, the company accrues expertise in international markets, maintains its level of billings and assures its capacity to respond to the requirements of the domestic market should public investments in infrastructure occur.

As for consolidation, the study shows that there is a type of continuum of different internationalization levels among the three companies with international activity. Company 4 has the lowest level of commitment to international activities, while company 3 is the one most heavily involved in it. Company 1 is closer to the highest commitment extreme. This may be represented thus:

Figure 2: Degree of Involvement with International Markets

\begin{tabular}{|c|c|c|c|}
\cline { 2 - 4 } \multicolumn{1}{c|}{} & \multicolumn{3}{c|}{ Degree of involvement with international markets } \\
\hline Domestic Market & Low to Moderate & Moderate & High \\
\hline & 4 & 1 & 3 \\
\hline
\end{tabular}

The classification of the companies in different levels of internationalization was based on the analysis of the data collected and grouped into the previously discussed categories (Table 2). Thus, the findings of the research showed that Company 3 has a long and enlarging international trajectory, effective commitment of resources and permanent presence in many countries, which means that it can be classified as having a high degree of involvement. Company 1 has undergone a process of retracting its international presence, decreasing its area of activity, but is still heavily involved with international markets. Considering this retraction and the opinions of the interviewees about its international participation, its involvement with international markets was classified as moderate. Finally, it was evident that Company 4 recently resumed its efforts at internationalization, has a few international operations and still has limited international involvement. For these reasons, its international engagement was classified as low to moderate.

Consolidation, studied from the perspective of maintaining international operations continuously and of the growth of these operations, was clearer in the case of company 3. However, one cannot say that 
the other two companies are not consolidated, since they too meet the criteria used to analyze the issue. Thus, the presence of companies 4 and 1 can be regarded as being consolidated in Latin America. In the case of company 1, at first sight one might say that it withdrew from the international arena and was therefore not consolidated. However, to examine the redefinition of the product-market domain in this way would be to disregard the context that explains the decision. The redefinition fulfilled a strategic reorientation of the group whereby the market was split between the Portuguese subsidiary and construction company 1 . Both the companies are wholly controlled by the Group, which shows there was no retraction in terms of international activity but rather a new solution to adaptive cycle problems (Miles \& Snow, 1978), resulting in the company's business being configured in a different way.

The description of the analysis categories in case 3 showed that the company heavily incorporated international activity into its scope of action, to the point of defining Brazil as its political-strategic management base. The consolidation of international presence is clearly observed in this company and its involvement with foreign markets has been growing non-stop ever since it first entered this field.

Considering the evolution of international market presence from the point of view of Douglas and Craig (1989), we found that the companies studied were distributed across different levels. Company 2 , during the period analyzed, can be allocated to the pre-international stage, whose focus of action is domestic, despite some prior experience in foreign markets. Companies 1 and 4 can be considered as representing stage 2, called expansion in the local market. Company 3 , in turn, can be classified as typical of stage 3 , global rationalization.

These analyses indicate that consolidation extends beyond the aspects of mere orientation vis-à-vis the market, whether international or global, for example. A company can operate on a country-bycountry basis and yet be consolidated. Furthermore, the companies researched verified this possibility. Although they may be different in terms of their involvement with and posture toward the markets in which they operate, their presence abroad can be seen as consolidated.

From this standpoint, it seems that consolidation can occur as a result of a company's ongoing presence in a single region (Latin America, for instance) or of its maintaining a global base of operation. We propose that it is not the number of countries reached that defines the level of consolidation, but the growth of external participation and the maintenance of operations abroad.

Therefore, one should understand consolidation from a perspective that differs from the one employed in the evolutionary type models, whose sequence of stages seems to build up to global operations compulsorily.

Thus, we attempted to identify, with empirical research as our starting point, which factors best explain consolidation in the companies studied. The data indicate that it occurred mainly as a result of factors related to strategic management (suitable response to the adaptive cycle), the reaction to institutional processes and adaptation to the sector's competitive conditions. Figure 3 shows what the empirical stage suggested.

The figure indicates that consolidation in foreign markets is expected under circumstances in which the company produces suitable responses to the three problems of the adaptive cycle, taking into account the network of influences amongst them. Another conditioning factor of consolidation is found in the occurrence of suitable responses to institutional demands. In other words, the possibility of consolidating international activity grows as the company identifies the main sources of institutional processes, monitors them and responds to them with precision. The third conditioning factor concerns adaptation to competitive dynamics. The study's empirical stage showed that in-depth knowledge of the industry's competitive structure is fundamental, as is adaptation to the minimum requirements needed to belong to the club. 
Figure 3: Conditioning Factors for Consolidation

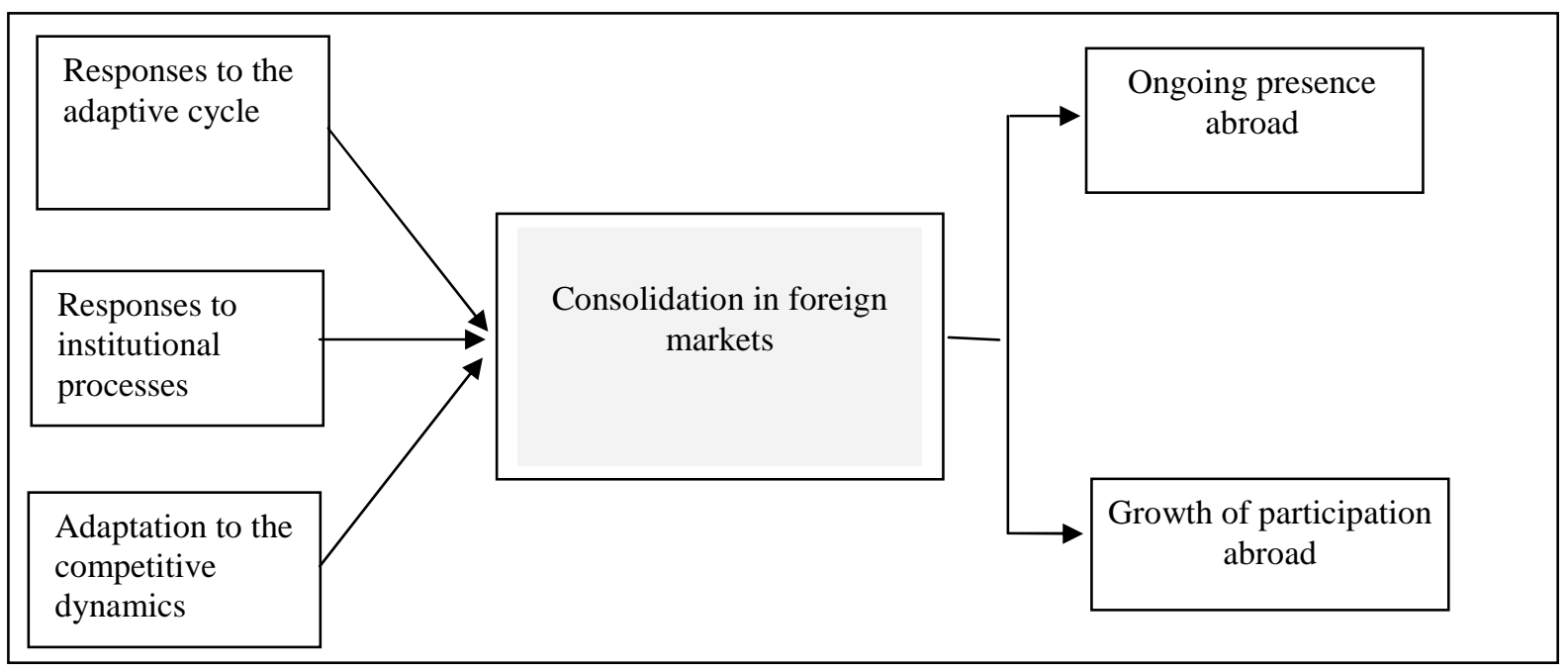

Therefore, the conclusion reached is that the consolidation in foreign markets of the companies studied seems to have occurred primarily as a result of the management model adopted. However, in the broad range of aspects that are covered by the definition of a management model, three factors appear to carry more weight in the heavy construction industry. The first one concerns adaptation to the foreign environment, starting with the dynamics of the adaptive cycle. As previously explained, the cases studied showed that it is crucial for companies to keep their decisions regarding markets, management and technology strictly aligned. When this does not happen, the company incurs losses that, depending on their magnitude, may or may not be recovered.

In case 2 , an inability to solve the administrative problem, mainly, led to its withdrawal back into the domestic market. This was also the case of company 4, after its first international incursion, in 1984. However, this company was able to maintain its financial muscle and to resume foreign operations. Construction companies 1 and 3 also made occasional mistakes in their strategic choices, but reacted by investing in other markets and/or streamlining their structure.

The response to institutional pressures was also highly relevant, because the interplay between forces drove the companies to embrace postures appropriate to the different situations. The concern with reaching compromises with local society was shown to be important and an influential factor on the outcome. An understanding of local culture is fundamental for the company to evaluate how best to respond to the specific demands put forth by the institutions, whether they come from the State, the Church or the Unions. Mere compliance, as it turns out, is not the only available path. Other strategies seemed more appropriate due to the surrounding context.

A third factor observed was the degree of adaptation to competitive conditions. The companies researched showed that the consolidation of their presence abroad required them to perfect their administrative systems and incorporate more complex management skills, to become able to respond to the requirements of the large construction projects.

\section{CONCLUSIONS}

The proposition of a theoretical model with four levels of influence was shown to be appropriate to the interests of this study. The notion that consolidation in foreign markets is a phenomenon subject to several conditioning factors was corroborated by the empirical evidence obtained from the four cases 
studied. An interrelation between the aspects of each analysis level was also identified, ratifying the complex and multivariate nature of internationalization.

That said, the model proposed appears to provide support for the study of internationalization to the extent that it enables the researcher to analyze the phenomenon from a viewpoint that is closer to the complexities that typify the process. Consequently, there is no intention of having consolidation be understood only from the standpoint of its management or of the impact of the macro-circumstances around it, for example. On the contrary, the model's proposal lies precisely in the evaluation of the multiple and inter-related conditioning factors whose impact must be observed within the particular context of the different industries, since this is the approach that encapsulates the phenomenon.

From this point of view, the authors believe that the propositions combined in the theoretical model are viable for analyzing the phenomenon because they allowed the study to be conducted fully and depicted the dynamics of consolidation in foreign markets. The combined use of conceptual structures borrowed from organizational theory, administrative theory and international business theory proved to be viable and necessary in order to fully capture the phenomenon. Thus, it is the authors' understanding that the empirical stage corroborated the model.

Considering the propositions put forth in the presentation of the theoretical model, the empirical stage showed that, where the analysis of the macro-context is concerned, the proposition that states that among the macro context's tendencies, those of an economic nature have the greatest impact on international activity and on consolidation abroad was borne out by the evidence provided by three of the four cases analyzed. Therefore, one cannot state that economic tendencies are actually the key ones for the consolidation process. It would be more appropriate to say that the cases indicated that the economy is an important factor for international activity, whose analysis always uses as a starting point the process of evaluating opportunities and restrictions to the expansion of operations.

On the same analytical level, the theoretical proposition that a company's failure to adapt to local culture restricts its consolidation abroad also failed to be fully corroborated by the companies analyzed, having been partially ratified in the four cases and fully confirmed only in case 3 . Although this may be the company with the strongest degree of internationalization activity, the data collected do not allow us to infer that its determining result was its adaptation to social and cultural factors. For this reason, the authors feel that this proposition was only corroborated in part.

At the institutional environment level, the empirical evidence corroborated the proposition that isomorphic processes are typical of the sector and influence decisions that concern foreign markets. The data pointed to markedly isomorphic behavior among the companies researched, reflected in a similarity of strategies, paths and postures. Therefore, the authors believe that the analysis of isomorphic processes should be included in studies about internationalization in order to enable a better understanding of the postures adopted and results obtained. This statement results from the fact that the processes that lead to homogenization are not usually guided by issues of efficiency. Wanting to belong to the club seems to explain many of the companies' decisions better.

As for the proposition that political institutions have the strongest impact upon the international operation and its consolidation, the data analyzed do not allow one to conclude that this group has the greatest influence, given that situations do occur in which the social and legal institutions took on the role of elements restricting consolidation, even leading companies to give up certain markets. Therefore, on the basis of the cases analyzed, one cannot state that a single group of institutions is more important for consolidation. It would be more appropriate to corroborate the influence of institutions in this process, the evaluation of which institutional aspect was the most important one (both as a stimulus and a restriction) being called for in each case.

At the same analytical level, the proposition that sustained that strategic responses to institutional pressures vary and may take on different degrees of submission or of active resistance was supported by the empirical stage and was shown to be an important factor in terms of explaining companies' results abroad. Thus, it became evident that in situations in which the construction 
companies felt that institutional pressure would be unfavorable, they adopted more active strategic response postures in an attempt to protect their own interests.

In relation to the industry analysis level, the proposition that in-depth knowledge of the specific resources that provide the company with comparative advantages is a determining factor of consolidation in foreign markets was partially supported by the empirical evidence. The data collected indicated that know-how regarding specific resources such as technology and knowledge are fundamental factors for company competitiveness, even though the interviewees did not point out this factor as a determining factor of consolidation, their position being that their availability is an indispensable condition for the construction company to continue operating.

Moreover, on the subject of the industry-level analysis, the study corroborated the proposition that the dynamics of the competitive relations influences the possibility of consolidating international activity. It appears that these dynamics influence the way in which companies conduct their business, as well as how they make their choices in market terms. Adaptation to competitive dynamics seems to be a prerequisite for attaining favorable positions abroad: the companies indicated that a management style was required of a type that would qualify them for bidding for constructions projects. In other words, the companies need to learn to manage their resources and competencies in such a way as to become able to embrace competitive and partnering postures simultaneously vis-à-vis other companies in their sector. Without this managerial know-how, international expansion suffers.

Moving on to the company level analysis, we found that the cases studied provided empirical support for the proposition that in international markets, decisions concerning each one of the problems of the adaptive cycle call for new solutions to the other problems. The companies studied showed that over the course of the international expansion path, they had to adjust the solutions to the problems of the adaptive cycle. To optimize results, the construction companies, for instance, went through processes of redefining the product-market domain, which generated the need for adaptation regarding other solutions.

Similarly, the proposition that the adjustment between the solutions to the administrative, engineering and entrepreneurial problems is a determining factor for consolidation in foreign markets was corroborated because the empirical stage showed that this adjustment always occurred during dynamic international expansion processes. The data raised show that the companies attempted to adapt to the environment through a solution to the said problems, considering the need for adjustments among the solutions. Thus, there was a predominance of situations in which the image projected by the company in market terms was corroborated by other postures linked to the administrative and the engineering problems, and vice-versa.

Taking into account the earlier exposition of the theoretical model, the authors believe that, generally speaking, empirical support was found, although some of their propositions were corroborated empirically only in part. On the other hand, the case studies did not provide different situations from those taken into account in the theoretical model. Therefore, one can conclude that the said structure is viable for the study of consolidation and, which is even more important, that it has the potential for being used in new studies of different industries.

Based on the proposed model, it seems that research designed to help minimize the scarcity of studies about the management of mature companies operating in foreign markets could be stepped up. In addition to the scientific relevance of such studies, the authors believe that a knowledge of the factors that condition consolidation in real situations can help to define strategies to encourage companies' internationalization, prioritizing the aspects that influence this process the most.

Another contribution is connected with the study of mature companies vis-à-vis international operations, brining into the debate issues that extend beyond the aspects related with choice of countries and means of entry into international markets, which seem to predominate in the studies currently conducted. 
In theoretical terms, we also believe that this article makes progress where understanding internationalization processes is concerned, in that it proposes a model that integrates knowledge from the fields of study of administration, organizations and international business. Though the model may be refined in future research, we believe that it reflects an important step toward the development of a broad theoretical frame of reference, one capable of covering the wealth and diversity that are typical of international activity. From this standpoint, the results of the study seem to have shown that the debate about institutions is an important theme for inclusion in the area's research agenda.

\section{REFERENCES}

Aaker, D. A. (2001). Administração estratégica de mercado (5th ed.). Porto Alegre: Bookman.

Arbix, G., Salerno, M. S., \& De Negri, J. A. (2004). Inovação, via internacionalização, faz bem para as exportações brasileiras. [Text for discussion $\mathrm{N}^{\mathrm{o}}$ 1023]. Instituto de Pesquisa Econômica Aplicada, Brasília, DF, Brasil.

Bardin, L. (2004). Análise de conteúdo (3rd ed.). Lisbon: Edições 70.

DiMaggio, P. J., \& Powell, W. W. (1991). The iron cage revisited: institutional isomorphism and collective rationality in organizational fields. In W. W. Powell, \& P. J. DiMaggio (Eds.). The new institutionalism in organizational analysis (pp. 63-82). Chicago: The University of Chicago Press.

Douglas, S. P., \& Craig, C. S. (1989). Evolution of global marketing strategy: scale, scope, and synergy. Columbia Journal of World Business, 24, 47-59.

Doz, Y. L., \& Prahalad, C. K. (1991). Managing DMNCs: a search for a new paradigm. Strategic Management Journal, 12(S1), 145-164.

Gonçalves, C. A., \& Meirelles, A. M. (2004). Projetos e relatórios de pesquisa em administração. São Paulo: Atlas.

Hunt, S. D. (2002). Foundations of marketing theory: toward a general theory of marketing. New York: M. E. Sharpe.

Javalgi, R. G., \& White, D. S. (2002). Strategic challenges for the marketing of services internationally. International Marketing Review, 19(6), 563-581.

Jlang, R. J., \& Bezmish, P. W. (2004, August). Timing and performance of post-entry foreign subsidiaries. Proceedings of the Academy of Management Meeting, New Orleans, Luisiana.

Li, J. (1995). Foreign entry and survival: effects of strategic choices on performance in international markets. Strategic Management Journal, 16(5), 333-351.

Malhotra, N. K. (2001). Pesquisa de marketing: uma orientação aplicada (3rd ed.). Porto Alegre: Bookman.

Mata, J., \& Portugal, P. (2004). Patterns of entry, post-entry growth and survival. Small Business Economics, 22(3-4), 283-298.

Melin, L. (1992). Internationalization as a strategy process. Strategic Management Journal, 13(S2), 99-118.

Meyer, J. W., \& Rowan, B. (1991). Institutionalized organizations: formal structure as myth and ceremony. In W. W. Powell, \& P. DiMaggio (Eds.). The new institutionalism in organizational analysis (pp. 41-62). Chicago: The University of Chicago Press. 
Miles, R. E., \& Snow, C.C. (1978). Organizational strategy, structure, and process. New York: McGraw-Hill.

Nicolaud, B. (1989). Problems and strategies in the international marketing of services. European Journal of Marketing, 23(6), 55-66.

Oliver, C. (1991). Strategic responses to institutional processes. Academy of Management Review, 16(1), 145-179.

Patterson, P. G., \& Cicic, M. (1995). A typology of service firms in international markets: an empirical investigation. Journal of International Marketing, 3(4), 57-83.

Raju, J. S., \& Roy, A. (1999). O conhecimento dos relacionamentos competitivos. In G. S. Day, \& D. J. Reibstein (Eds.). A dinâmica da estratégia competitiva (pp. 228-240). Rio de Janeiro: Campus.

Rocha, A. da, \& Arkader, R. (2002). Internacionalização e escolhas estratégicas na indústria de autopeças. In A. da Rocha (Ed.). A internacionalização das empresas brasileiras: estudos de gestão internacional (pp. 143-167). Rio de Janeiro: Mauad.

Rodrigues, S. B. (2003, August). The political and institutional dynamics of culture change. Proceedings of the Academy of Management Meeting, Seattle, WA, USA.

Scott, W. R. (1995). Institutions and organizations. London: SAGE Publications. 